Received : 2019-06-23 Revised : 2019-06-26 Acceptance : 2019-06-27 Publish : 2019-07-22

\title{
THE CORRELATION BETWEEN ROLE AND FAMILY SUPPORT TOWARD THE BLOOD PRESSURE ON THE PATIENT HYPERTENSION IN TANJUNG ISUY VILLAGE KUTAI BARAT
}

\author{
Annaas Budi Setyawan ${ }^{1}$ \\ ${ }^{1}$ Department of Nursing, Faculty of Health and Pharmacy, Universitas Muhammadiyah \\ Kalimantan Timur \\ Corresponding Author : abs564@umkt.ac.id
}

\begin{abstract}
The role of the family is needed in providing support to hypertensive patients to be diligently checked themselves to the place of health care for regular blood control. One of the problems faced by the community, among others, is the lack of support and care from family members and the community in routine health checks. To know and see if there is a relation of role and support of family with blood pressure in hypertension patient in Tanjung Isuy village, Jempang Subdistrict of Kutai Barat Regency. The research method used in this study is a correlation study method with the cross-sectional approach, with a total sample of 35 people. Bivariate tests using the Spearman rank correlation test. The value of $p$ value from family role variables with blood pressure that is $p=0,000<0.05$ which means concluded that there is a significant relation between family roles with the blood pressure of hypertension patients. Family role with blood pressure that is $\mathrm{p}=0.003<0.05$ which concluded that there is a significant relation between family support with a blood pressure of hypertension patient. There is a significant correlation between family role and support with blood pressure in hypertensive patients in Tanjung Isuy village, Jempang sub-district, West Kutai regency.
\end{abstract}

Keywords: Hypertension ; Family role; Family support

\section{INTRODUCTION}

Hypertension is the number one cause of death in the world. This statement is strengthened, which states that there are one billion people in the world suffering from hypertension and an estimated 7.5 million deaths or around $12.8 \%$ of all deaths caused by this disease. About 77.9 million people in the United States or 1 in 3 adults suffer from this disease. It is even expected to continue to increase by $7.2 \%$ or around 83.5 million people in $2030^{1}$.

Hypertension or high blood pressure is an increase in systolic blood pressure of more than $140 \mathrm{mmHg}$ and diastolic blood pressure of more than $90 \mathrm{mmHg}$ at two measurements with an interval of five minutes in a state of sufficient rest/calm. Hypertension is a disorder in the 
circulatory system that can cause an increase in blood pressure above the normal value, which exceeds systolic $140 \mathrm{mmHg}$ and diastolic $90 \mathrm{mmHg}^{2}$.

Based on Indonesia's Basic Health Research in 2013, East Kalimantan Province was ranked as the third-largest sufferer of hypertension, namely: 1,218,259 people (29.6\%). District / City Health Profile in East Kalimantan province in 2013, which is the 10 most types of diseases, the picture can be seen as follows. Patients with Primary Hypertension in East Kalimantan Province in 2013, as many as 190,866 people, or $14.62 \%$ and ranked second out of 10 most diseases, including Common Cold / ARI, amounting to 614,231 people (47.04\%), Gastritis, amounting to 190,866 people (13.12\%) , Myalgia / Rhematoid, 85,683 people (6.56\%), Dermatitis, eczema, 56,678 people (4.34\%), Pulp \& Perapical Tissue Diseases, 48,527 people (3.72\%), Diarrhea and Non-specific gastroenteritis, 48,290 people (3.70\%) \%), Diabetes Mellitus, 34.793 people (2.66\%), Chepalgia, 29.945 people (2.29\%), Other Degenerative Diseases, 25.290 people (1.94\%). Total 1,305,660 people or $100 \%{ }^{3}$.

The role of the family is very much needed in providing support to hypertensive patients to be diligent in checking their health care facilities for routine blood control. The role of the family is the presence of the family to meet the needs of family members and the ability of the family to respond to changes through the flexibility of the role and family have a very large influence in a variety of medical actions to be carried out, both diagnosis, prevention of disease, treatment and care ${ }^{4}$.

The role of the family is very influential in community participation. If family members are very instrumental, then the community will participate according to the attitude of family members. One of the problems faced by the community is the lack of support and care from family members and the community for routine health checks, which has an impact on the level of community visits to Posbindu PTM. Community environment is one of the factors that influence the formation and development of individual behaviour, both the physical environment and the socio-psychological environment, including learning 5 .

Family support is very instrumental in encouraging someone's interest or willingness to participate in Posbindu activities. The low population attendance in Posbindu can be influenced by the lack of family support ${ }^{6}$. The results showed that the lack of family support due to lack of knowledge from other family members about health care performed by his own family. This is consistent with the theory that individuals need social support, one of which comes from the family. Low family support is due to working family members, so they do not pay attention to the importance of health checks in disease prevention efforts ${ }^{7}$.

Family support for patients with hypertension is needed in controlling the increased frequency of hypertension recurrence to one family member. Family support is the attitude, actions and acceptance of the family of its members. Family members view that people who are supportive are always ready to provide help and assistance if needed Friedman ${ }^{8}$. 
In a preliminary study conducted by researchers in January 2016, from data from the District Health Office in West Kutai District, it was found that hypertension sufferers in 2014 reached 3,764 people, and during 2015, the number of hypertension sufferers was found to be 6,226 people. While the data for the working area of the Tanjung Isuy Health Center in the District of Jempang, West Kutai Regency itself, patients with hypertension during in 2014, amounting to 515 people, and data for 2015 there were 997 people. Specifically for the village of Tanjung Isuy, Jempang Subdistrict, West Kutai Regency itself, data obtained during February, March and April 2015, hypertension sufferers were 99 people, and for February, March and April 2016 there were 113 people. This data was obtained based on the results of the medical record (Simpus) of Tanjung Isuy Puskesmas in Jempang District, where hypertension sufferers who had come for treatment at Tanjung Isuy Puskesmas in Jempang District. From a preliminary study conducted by researchers with direct interviews on 11 patients with hypertension in two Posbindu in the Tanjung Isuy village area, it appears that the level of role and support of families with blood pressure in hypertension is still not good. The initial indicator was that of the eleven hypertension patients who came to Posbindu and health facilities it turned out that 7 patients were alone without their family when they visited Posbindu, while 4 patients were escorted and accompanied by their respective families.

This paper wants to shed light on whether or not there is a relation between the role and family support with blood pressure in patients with hypertension in the village of Tanjung Isuy, Jempang District, West Kutai Regency.

\section{MATERIAL AND METHODS}

The research method used in this study is a correlation study research method with a cross-sectional approach where the researcher approaches, observes or measures data at once (point time approach). This was done to see the relation between the role and family support variables with the blood pressure of hypertension sufferers in Tanjung Isuy Village, Jempang District, West Kutai Regency. The inclusion criteria in this study were patients who were diagnosed with primary hypertension by a doctor at the Tanjung Isuy Puskesmas and were willing to become respondents (signed by the informed consent). Exclusion criteria in this study were patients with accompanying mental disorders. Samples were taken as many as 35 respondents from a total population of 35 respondents, obtained from the data of the Tangjung Isuy Public Health Center symposium from April 2018. The reason the researchers conducted research at this place is because it is known from the data (Simpus) of the Tanjung Isuy Health Center in Jempang District, West Kutai Regency, that high rates of hypertension sufferers To see the relation of the role and support of families with blood pressure Hypertension Patients use the spearmen rank correlation test with p-value 0.05 . 


\section{RESULTS}

\section{1. Characteristics of Respondents}

table 1. Characteristics of respondents with hypertension in Tanjung Isuy Village, Jempang District 2018

\begin{tabular}{|c|c|c|}
\hline Characteristics & Frequencies & Percentage \\
\hline \multicolumn{3}{|l|}{ 1. Gender } \\
\hline Men & 11 & 31,4 \\
\hline Women & 24 & 68,6 \\
\hline \multicolumn{3}{|l|}{ 2. Age } \\
\hline 46-55 tahun & 6 & 17,1 \\
\hline 56-65 tahun & 12 & 34,3 \\
\hline$>65$ tahun & 17 & 48,6 \\
\hline \multicolumn{3}{|l|}{ 3. Education } \\
\hline No School & 18 & 51,4 \\
\hline Elementary School & 7 & 20,0 \\
\hline Junior High School & 6 & 17,1 \\
\hline High School & 4 & 11,4 \\
\hline \multicolumn{3}{|l|}{ 4.Work } \\
\hline Farmers & 15 & 42,9 \\
\hline Private & 5 & 14,3 \\
\hline Civil Servants & 2 & 5,7 \\
\hline Doesn't Work & 13 & 37,1 \\
\hline Total & 35 & 100 \\
\hline
\end{tabular}

Primary data source 2018

2. Role of the Family

Table 2. Role of the Family in Patients with Hypertension in Tanjung Isuy Village, Jempang Kutai Barat District 2018

\begin{tabular}{ccc}
\hline Role of Family & Frequency & $(\boldsymbol{\%})$ \\
\hline Not Good & 13 & 37,1 \\
Good & 22 & 62,9 \\
\hline Total & $\mathbf{3 5}$ & $\mathbf{1 0 0}$ \\
\hline
\end{tabular}

The primary data source 2018

3. Family Support

Table 3. Family Support for Patients with Hypertension in Tanjung Isuy Village, Jempang Kutai Barat District 2018

\begin{tabular}{ccc}
\hline Family Support & Frequency & $(\boldsymbol{\%})$ \\
\hline Not Good & 9 & 25,7 \\
Good & 26 & 74,3 \\
\hline Total & $\mathbf{3 5}$ & $\mathbf{1 0 0}$ \\
\hline
\end{tabular}

The primary data source 2018 
4. Blood Pressure Patients with Hypertension

Table 4. Blood Pressure in Hypertension Patients in Tanjung Isuy Village, Jempang Kutai Barat District 2018

\begin{tabular}{ccc}
\hline Blood Pressure & Frequency & $(\boldsymbol{\%})$ \\
\hline Pre Hypertension & 22 & 57,1 \\
Hypertension Degrees I & 8 & 28,6 \\
Grade II hypertension & 5 & 14,3 \\
\hline Total & $\mathbf{3 5}$ & $\mathbf{1 0 0}$ \\
\hline
\end{tabular}

The primary data source 2018

5. Relation of the Role of Family with Blood Pressure in Patients with Hypertension

Table 5. Relation of the Role of Family with Blood Pressure in Hypertension Patients in Tanjung Isuy

Village, Jempang Kutai Barat District 2018

\begin{tabular}{ll}
\hline Variable & Blood Pressure \\
\hline & $\mathrm{r}=0,643$ \\
Role of the Family & $\mathrm{p}=0,000$ \\
$\mathrm{n}=35$
\end{tabular}

The primary data source 2018

6. Relation of Family Support with Blood Pressure in Patients with Hypertension

Table 6 Relation between Family Support and Blood Pressure in Patients with Hypertension in

Tanjung Isuy Village, Jempang Kutai Barat District 2018

\begin{tabular}{ll}
\hline Variable & Blood Pressure \\
\hline & $\mathrm{r}=0,492$ \\
Family suport & $\mathrm{p}=0,003$ \\
$\mathrm{n}=35$
\end{tabular}

The primary data source 2018

\section{DISCUSSION}

Based on the characteristics of the sex, it was found that most of the women were 24 people $(68.6 \%)$ and men were 11 people $(31.4 \%)$. The results of this study are in line with research conducted also found that women suffer more hypertension than men, most of which are 49 women (58\%) and almost half are 37 men (42\%). The prevalence of hypertension in men is the same as women. But women are protected from cardiovascular disease before menopause. Women who have not yet experienced menopause are protected by the hormone estrogen which plays a role in increasing HDL levels. High levels of HDL cholesterol are protective factors in preventing the process of atherosclerosis ${ }^{9}$.

revealed that the overall prevalence of hypertension events aged 18 years and over for men and women is the same. Statistically, the prevalence of hypertension for men (29.7\%) is slightly higher than for women $(28.5 \%)$. This is caused by the style and lifestyle demands as well 
as the attitude to deal with the condition of hypertension. Hypertension in men tends to be influenced by smoking, alcohol consumption, and work-related stress ${ }^{10}$. Seeing from the attitude to face hypertension, women tend to be more concerned with the conditions experienced, for example by consulting the condition to the doctor. According to researchers' assumptions, the number of women with hypertension is higher than men due to the decrease in the hormone estrogen they have due to having entered menopause (> 55 years) so that HDL cholesterol levels are unable to protect women from the process of atherosclerosis.

Based on the age characteristics of the respondents it was found that most of the age $>65$ years were 17 people (48.6\%), then aged 56-65 years were 12 people and aged 46-55 years were 6 people $(17.1 \%)$. This result is in line with previous research, the number of respondents with hypertension is almost half $>65$ years old, which is $43.7 \%{ }^{11}$. These results are consistent with the theory that the incidence of hypertension continues to increase with age, the incidence of hypertension is prevalent in the age group $>75$ years $^{12}$. Epidemiological data indicate that with the increasing population of the elderly, the number of patients with hypertension is also likely to increase, where both systolic hypertension and a combination of systolic and diastolic hypertension often occur in more than half of people aged $>65$ years. Someone who is over 60 years old, $50-60 \%$ of them have blood pressure higher or equal to $140 / 90 \mathrm{mmHg}^{13}$.

The incidence of hypertension increases with age. often caused by natural changes in the body that affect the heart, blood vessels and hormones. Hypertension will increase with age from $5 \%$ at the age of 20 years to $45 \%$ at the age of 70 years. This is in line with the results of research conducted that with increasing age the risk of hypertension can increase even though hypertension can occur at any age, but is most often found at the age of 35 years or more ${ }^{14}$. This is caused by natural changes in the heart, blood vessels and hormones. From the description above, the researchers are of the opinion that the age group $>65$ years who experience hypertension is more because at that age many natural changes occur in the heart, blood vessels and hormones. Thus these changes result in decreased elasticity of blood vessels to change and increased blood pressure. From the results of the study, it was found that several respondents at a young age were affected by hypertension. This is influenced not only by age but also because of other factors such as high salt consumption habits, obesity and stress.

Based on the characteristics of education, it was found that most respondents did not attend school as many as 18 people $(51.4 \%)$, respondents who were elementary school were 7 people $(20.0 \%)$, junior high school were 6 people $(17.1 \%)$ and high school were 4 people (11, $4 \%$ ). The results of this study are in line with research conducted entitled the relation between education level and the degree of hypertension in the Wonorejo village, where most of the respondents with no education are 35 people $(65.5 \%)^{15}$. the level of education greatly influences how a person acts and looks for causes and solutions in life ${ }^{16}$. The low level of education of the respondent is related to the period when the respondent was at school age. 
The education level of the respondents is related to the ability of respondents to understand information about stress management. This level of education helps one to understand the knowledge of stress management ${ }^{17}$. Researchers assume education is one of the factors that greatly determine one's knowledge and perception of the importance of something, including the importance of knowledge about managing hypertension. This is because someone who has low education is more difficult to accept something new.

Based on the characteristics of respondents regarding work, it was found that most respondents worked as farmers 15 people $(42.9 \%)$, then as laborers as many as 13 people (37.1\%), private as many as 5 people (14.3\%) and civil servants as many as 2 people ( $5.7 \%)$. This result is in line with research conducted entitled the description of risk factors about hypertension in the Tering Health Center which said that the majority of respondents were farmers and gardening as many as 45 people $(65.5 \%)^{18}$. Work is not a source of pleasure, but more ways to make a living as human nature. The high work participation in the population is caused by several factors, including the structure of the population, the improved socioeconomic level of the community, the longer life expectancy of the population, the reach of health services, and the improved health status of the population.

Work is an activity or activity of someone who works for another person or agency, office, company to earn income that is wages or salary in the form of money or goods to meet the needs of daily life. Low income will be related to the utilization of health services and prevention. Someone not utilizing existing health services maybe because they do not have enough money to buy drugs or pay for transportation ${ }^{16}$. According to the researchers' assumptions that differences in quality of life-based on work occur because of differences in workload, the environment and how satisfied respondents enjoy their activities. It is recommended that respondents be provided with educational services related to light activities intended to fill their daily lives.

The results of the bivariate analysis of the relation between the role of family and blood pressure obtained $p$-value of the family role variable with blood pressure, that is $p=0,000<0.05$ which means Ho was rejected and it can be concluded that there is a significant relation between the role of family with blood pressure of hypertension sufferers. Based on the above data it is known that the Spearman Rank correlation results are $r=0.643$ which has a positive correlation and high correlation strength, which means the better the role of the respondent's family, the lower the blood pressure of hypertension. The results of this study are in line with research conducted entitled the relation of family roles to the compliance of hypertension patients in Batu Desa, North Minahasa Regency, where the results obtained p-value: $0.002(<0.05)$ which means there is a relation between family roles with compliance with treatment of hypertensive patients. A role is a set of behaviour expected by another person towards someone, according to their position in a system ${ }^{19}$. The role is influenced by social conditions both inside and outside, and when it is stable. The roles related to each of these positions are a number of roles in terms of family position ${ }^{20}$. 
The role or role is a function or behaviour that is expected to exist in individuals as an activity that includes domestic roles and public roles. Moral and material encouragement were given by family members to realize a plan is something that can provide emotional benefits or influence on one's behavior. The understanding of the role of the family is the presence of the family to meet the needs of family members and the ability of the family to respond to changes through the flexibility of the role and family has a very large influence in a variety of medical actions to be carried out, both diagnosis, disease prevention, treatment and care ${ }^{4}$.

The role itself is a set of behaviours expected in accordance with the given social position. For the proper functioning of roles is very important not only for the successful functioning of individuals but also for the success of family functions. Family functions are achieved through the appearance of family roles ${ }^{4}$.

The family has a role or function to carry out health care practices, which is to prevent health problems and / or care for sick family members. The ability of families to provide health care affects the health status of the family. The ability of the family to carry out health maintenance can be seen from the existing family health tasks. A family that can carry out health tasks means being able to solve health problems. Basic functions and family tasks are one of them providing care to family members who have health problems, with the aim that family and family members can be met their health needs ${ }^{4}$.

According to the author's analysis of the role of the family is the presence of the family to meet the needs of family members and the ability of the family to respond to changes through the flexibility of the role and family has a very big influence in a variety of hypertension treatment measures that can be done such as dietary arrangements, sports regulation and blood pressure checking settings.

Bivariate analysis results between family support with blood pressure p-value values obtained from the role of family variables with blood pressure are $p=0,000<0.05$ which means Ho is rejected and it can be concluded that there is a significant relation between family support with the blood pressure of hypertension sufferers. Based on the above data it is known that the Spearman Rank correlation results are $\mathrm{r}=0.492$ which has a positive correlation and the correlation strength is moderate which means the better the support of the respondent's family, the lower the blood pressure of hypertension. These results are in line with research conducted by Isra (2017) entitled the relation of family support with the degree of hypertension in hypertensive patients at Ranomuut Public Health Center in Manado, p value: 0,000 $(<0.05)$, which means there is a relation between family support and the degree of hypertension.

Family support is any form of positive behaviour and attitude given by the family to one of the sick family members, family support consisting of informational support, appreciation, emotional and spiritual which is an integral part of overall support that is centered on the family approach to patients to improve health patients ${ }^{4}$. 
Hypertension cannot be cured, but can only be controlled so it requires patience and optimism. Hypertension requires a lifetime of treatment, social support from others is needed in undergoing treatment. Support from family and friends affects someone's compliance in carrying out health programs and also in general people who receive the comfort, attention and help they need from a person or group usually tend to be easier to follow medical advice. The family motivates patients to be obedient in carrying out treatment programs and sufferers have the behavior to develop feelings of being able, able to control themselves and be confident in solving problems. If this can work well, then family support will be very effective in supporting patient compliance in undergoing treatment programs ${ }^{11}$.

In accordance with the theory of family support according to Jhonson and Leny, (2010).family support is the attitude, actions and family determination of patients who are sick. Family support is needed by a sufferer because someone who is sick of course requires attention from the family. Attention from the family can be in the form of affection, attention and support for medication adherence. Families with good support, of course, will always remind to take medicine when it's time to take medicine. While the lack of family support, they are busy with their own affairs so they pay less attention to families who are sick.

According to the researchers' assumptions of hypertension treatment given every day, it must be supported by families, one of whom is by taking medication regularly because it will affect the treatment of hypertension and prevent worse complications. In addition, family support for hypertensive patients must be done continuously to reduce morbidity and mortality rates of hypertensive patients.

\section{CONCLUSION}

There is a relation between the role and support of families with blood pressure in patients with hypertension in the village of Tanjung Isuy, Jempang District, West Kutai Regency. It is expected that health workers should provide health education, not only for people with hypertension, but also for their immediate family to be able to participate in reminding and providing motivation in undergoing hypertension treatment.

\section{ACKNOWLEDGEMENT}

Thank you to the Head of Nursing D3, Ns. Ramdhany Ismahmudi, MPH who has given research permission. Thank you to Ms. Keli Lediana, SKM as the Head of the Tanjung Isuy Public Health Center for giving permission for data collection in this study.

\section{REFERENCES}

1. Erpandi. Posyandu Lansia Mewujudkan Lansia Sehat Mandiri dan Produktif. Jakarta : EGC. (2015). 
2. AB Setyawan. Efektivitas Senam Diabetes Melitus Untuk Menurunkan Kadar Kolesterol Pasien Diabetes Melitus. Jurrnal Husada Mahakam, 1,1, (2017)

3. East Kalimantan Provincial Health Office, Profil of Health East Kalimantan. (2014).

4. Jhonson, L., \& Leny, R . Keperawatan Keluarga. Yogyakarta : Graha Ilmu. (2010).

5. AB Setyawan, ES Lestari, W Winarto. Ekstrak Daun Kejibeling Meningkatkan Fagositosis Dan Roi Makrofag Pada Mencit Diinfeksi Staphylococcus aureus. Jurnal Kesehatan masyarakat 11,2,(2016)

6. Sunartyasih. Hubungan Kendala Pelaksanaan Posbindudengan dengan Kehadiran Lansia di Posbindu RW 8 Kelurahan Palasari Kecamatan Cibiru Bandung. Prosiding Seminar nasional Vol 3 N0 1.(2012).

7. Umayana, H. T., \& Cahyati, W. H. Dukungan Keluarga dan Tokoh Masyarakat Terhadap Keaktifan Penduduk ke Posbindu Penyakit Tidak Menular. Jurnal Kesehatan Masyarakat, 11(1), 96-101. (2015).

8. Muhlisin, Abi. Keperawatan Keluarga. Jogjakarta : Gosyen Publishing (2012).

9. Anggraini. Faktor- Faktor yang Berhubungan dengan Kejadian Hipertensi Pada Pasien yang berobat di Poliklinik Dewasa Puskesmas Bangkinang Periode Januari 2009. (2009).

10. Nwankwo, T., Yoon, S.S., Burt, V., Gu, Q.. Hypertension Among Adults in the United States: National Health and Nutrition Examination Survey, 2011- 2012. NCHS. 133:1-8 (2013).

11. Bolivar, JJ., Essential Hypertension: An Approach to Its Etiology and Neurogenic Pathophysiology. Int J Hyper. 547809. dx.doi.org/10.115/2013/547809 (2013).

12. Mohan, C.V., A Study of Serum Uric Acid Level in Patients With Essential Hypertension. Indian Journal of Applied Research. 6(1): 78-9 (2016).

13. Putra, RT. Pendekatan Klinis Hipertensi. In: Siti Setiati dkk (ed). Buku Ajar Ilmu Peyakit Dalam Jilid II Edisi VI. Jakarta: FKUI, pp: 3180-1 (2014).

14. Krishnan, Anand., Garg, Renu., Kahandaliyanage, Athula., Hypertension in the South-East Asia Region. Regional Health Forum. 17(1): 7-14 (2013).

15. Yoga. Relation Between Education Level And The Degree Of Hypertension In The Wonorejo Village (2010).

16. Notoatmodjo, S. Metodologi Penelitian Kesehatan. Edisi Revisi-Cetakan Kedua. Jakarta : PT Rineka Cipta. (2010).

17. Potter, P.A.\& Perry, A.G. Fundamental of Nursing: Concept, Proses and practice. Philadelpia: Mocby Years Inc.( 2012).

18. Joko B W. Faktor-Faktor Resiko Terjadinya Hipertensi di Puskesmas Tering (2011).

19. Bayu. Hubungan Antara Dukungan Keluarga Dengan Komplikasi Pasien Hipertensi Di Desa Batu Kelurahan Minahasa Utara. (2012).

20. Armillawati. Peningkatan Tekanan Darah. Jakarta: EGC.(2017). 